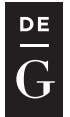

Politics in Central Europe (ISSN: 1801-3422)

Vol. 11, No. 2

DOI: 10.1515/pce-2015-0011

\title{
In the Eyes of the Collapsing Empire: Yugoslavia's Disintegration and Slovenian Independence as seen through Russian Diplomatic Sources (1990-1992)
}

\author{
ANDREJ STOPAR
}

\begin{abstract}
It is of critical importance for every newly established state to receive international recognition. The Soviet Union strongly supported the unity and territorial integrity of the Socialist Federal Republic of Yugoslavia and considered the latter's break-up within the context of its own disintegration. The article sets out Slovenia's efforts to gain Russian recognition of Slovenian independence and sovereignty, as described in Soviet and Russian diplomatic sources, official statements and comments from academic circles. It aims to demonstrate that Moscow's decision on this subject was the result of the momentary overlapping of various international developments along with a new Russian foreign policy strategy (which changed frequently and was, thus, exceptional in the Russian foreign policy tradition). Especially important in this context were the internal political tensions in the Russian Federation after the collapse of the Soviet Union.
\end{abstract}

Keywords: Soviet Union, Russia, Yugoslavia, Slovenia, diplomatic relations, collapse of socialist federations

At the close of the 1980s, Europe faced two opposing processes: the disintegration of multinational socialist federations on the one hand and a tendency towards European integration on the other. With the collapse of continental empires after World War I, the concept of the nation state, which had gradually gained ground in Europe after the Peace of Westphalia (1648), became a postulate for an understanding of statehood built on a triad of principles: sovereignty, integrity and self-determination (Simoniti 1996: 46). The states that emerged in Europe after 1990 claimed such self-determination as a basic and inalienable

1 The work was partly financed by the European Union, the European Social Fund and the Ministry of Education, Science and Sport under the Operational Programme for Human Resources Development for 2007-2013 (ESS-OP-07-13) 
right and the realisation of their dream of establishing their own statehood. In contrast, developed countries no longer regarded the concept as acceptable as they had during the Cold War when they held that self-determination derived from liberal notions of justice and equality and thus contributed to the strengthening of the peace (Simoniti 1996: 46). This change of view was forced upon them by the reality that the achievement of the emancipation plans of individual self-determination-invoking nation had led to conflict and war. Exercising the right to self-determination came to be seen above all as a violation of the principle of the territorial integrity of states. In exercising this right, independence-seeking nations were said to seize the political moment for their own advantage with no consideration of the consequences for others since their focus was merely on their own project (Simoniti 1996: 47). In the Balkan context, Simoniti adds diplomatically that the "Croatian "secession," which followed that of Slovenia, triggered a four-year war between the Serbs, Croats and Muslims.' According to Božo Repe (2002:8), however, the vast majority of the international political, diplomatic and intellectual community maintains that it was Slovenia's secession which set in motion the disintegration of Yugoslavia and the bloody war in the Balkans. The Russian analysis of this issue is quite similar if slightly more trenchant. Some Russian authors do not even consider that Slovenia's emancipatory ambitions were based on a quest for the democratisation of Slovenian society:

It is not surprising that the desire of Slovenia and Croatia to break away from Yugoslavia was expressed not through the struggle for "democracy" against the "communist center," but above all through their aspirations to integrate with European structures. This coincided with the general military-political objectives of the Western states in exercising their concept of NATO expansion (Vasileva - Gavrilin - Mirkiskin 2005: 337).

Some Russian authors have qualms about the Slovenes' state-building aspirations and their desire for a truly independent state. Yelena Ponomareva (2010:9), for instance, cannot find a single example in Slovenian history that would testify to a struggle for national independence:

The Slovenes did not have their own state until 1945 when they won recognition as a state-building nation and, as a titular nation, obtained their own republic - the People's/Socialist (since 1963) Republic of Slovenia. What is more, the national history of the Slovenes knows nothing about a national liberation struggle for independence.

Ponomareva finds reasons for this situation in the high level of development experienced by the Slovenian provinces during the Austro-Hungarian monarchy 
and maintained by them in both the monarchic and federal Yugoslavia. In her opinion, the Slovenes had no particular need to attain sovereignty and when they did so, this was based solely on the influence of foreign powers:

On the other hand, the centuries-old custom of being politically "attached" to the Slovenian political class was formed as a persistent reflex of dependency on external powers, whose leading role was determined by the hegemony in the region. [...] I may argue that Slovenia would have never demanded independence without the profound transformation of the system of international relations. However, once it declared sovereignty, it failed to truly fathom and feel it. Thirteen years after Slovenia voted for independence in a referendum and declared independence on 25 June 1991, it ceded a major part of its sovereignty to the European Union (2004) (Ponomareva 2010: 9-10).

Seen in this light, it is particularly interesting to observe how the creation of the new post-Yugoslav states was followed and received in an environment that was closely akin to Yugoslavia albeit one that was bigger and more consequential for world politics - the Soviet Union. This is despite the fact the leader of this similarly collapsing multinational state, Mikhail Gorbachev - at least officially underestimated the existence of the so-called national question:

If the national question had not been solved in principle, the Soviet Union would never have had the social, cultural, economic and defence potential it has now. Our state would not have survived if the republics had not formed a community based on brotherhood and cooperation, respect and mutual assistance (Gorbachev 1987: 118).

Much later, Gorbachev (1992: 175-176) would admit that it had taken him too long to fully grasp the pressing importance of the national question in the Soviet Union. Gorbachev's belated proposal of a new federal treaty among the sovereign republic not only led to a failed attempted coup in August 1991 when a conservative circle of his close associates tried to prevent the scheduled signature of the agreement on August 20, but fell completely short of suppressing the 'parade of sovereignties' (1988-1991) in which one Soviet republic after another declared sovereignty and then independence. ${ }^{2}$

Nevertheless, the structural and ideological similarity between the Soviet Union and socialist Yugoslavia alone would hardly have sufficed to create a climate in which to commence dialogue between Moscow and Ljubljana, the capital of the emerging Slovenian state. Until Slovenia, whose situation recalled that of the Soviet republics pursuing their independence, became a sovereign

2 Parad suverenitetov. Available at https://ru.wikipedia.org/wiki/_ (accessed on 01 April 2015). 
state, the two capitals could not engage in a dialogue of equals. These talks finally commenced after 14 February 1992 when the barely established Russian Federation recognised the independent Slovenia. The material available from the Soviet embassy in Belgrade, the Russian consulate-general in Zagreb and the Third European Administration of the USSR Ministry of Foreign Affairs (USSR MFA) in the archives of the Ministry of Foreign Affairs of the Russian Federation is not sufficient to allow for a comprehensive sense of the Soviet - or rather, Russian - understanding of Yugoslavia's collapse. It does, however, give us some idea of how the Soviet Union's foreign policy was shaped during the Union's disintegration. Based on media depictions and the memoirs of then key political figures and their advisers, we can infer that the Russian Federation's decision to recognise the new states of the post-Yugoslav expanse was a consequence of the short-term foreign policy priorities and tense internal politics which marked the early Yeltsin era.

\section{"Constructive Parallelism"}

It is evident from the memoirs of Vadim Medvedev, ${ }^{3}$ who escorted Gorbachev on his official visit to Yugoslavia between 14 and 18 March 1988, that the Soviet leaders were quite well abreast of Yugoslavia's internal affairs. The visit also enabled them to learn more about the positions of the Slovenian republican leadership:

I have already been to Slovenia and its capital Ljubljana. The image of the republic spoke volumes of its affiliation, which was more to Western than Eastern Europe: carefully cultivated land, dotted with beautiful houses and countless churches with highly inventive architecture, set against the backdrop of snowy Alpine peaks. Ljubljana is a tiny but all the more comfortable, well-organised city with a Western European lifestyle (Medvedev 1994: 490).

The Slovenian leadership seems to have been very eager to show their Soviet guests how very special, independent and "Western" Slovenia was. They even compared Slovenia's economic data with the Austrian and Italian equivalents rather than the Yugoslav average or respective Serbian and Croatian statistics. Medvedev detected clear suggestions that an autonomous Slovenia made independent from the federation could accomplish far more:

The President of the Presidency of the Central Committee of the League of Communists of Slovenia, Milan Kučan, elaborately explained his view of the

33 A politician, economist and academic, Vadim Andreevich Medvedev (1929) served as CPSU central committee secretary between 1986 and 1990. He then worked at the Economic Institute of the Russian Academy of Sciences and Arts and the Gorbachev Fund. 
political and economic reforms programme in socialist states, which could be viewed as a public demonstration of Slovenia's autonomy. [...] Interestingly, Kučan's programme was very similar to both the ongoing and anticipated reforms in the Soviet Union. As though they were trying to tell us: 'It doesn't matter what happens in Belgrade, the basis for political cooperation between Slovenia and the Soviet Union is here' (Medvedev 1994: 492).

Medvedev (1994:499-500), however, concluded that 'the visit to Yugoslavia [...] only further strengthened the Soviet conviction that Yugoslavia should be supported as a united federal state pursuing its democratic development. Such support was an organic, constitutive part of Soviet politics [...].'

Nonetheless, an opportunity for cooperation presented itself in the form of establishing of relations and collaboration between Slovenia and the individual Soviet republics. The success of these bilateral relations was most evident in the contact with Belarus ${ }^{4}$ and in subsequent talks with Ukraine during the latter's independence process (and in Ukraine's swift recognition of Slovenia on 12 December 1991). The potential was, in principle, also there in the relations with Russia, whose then foreign minister, Andrei Kozyrev endeavoured to establish cooperation at a regional level:

I personally, both in the Soviet Union and abroad, have always encouraged such a "constructive parallelism." Naturally, we must not face the foreign partners with a choice which would be dangerous or difficult for them to make: either the Union or the republics. From my viewpoint, relations should develop on a parallel basis, that is, both with the Union and the republics. Russia has an interest in having the shoots of new relations with the Soviet Union and the West not only preserved but also strengthened (Razuvaev 1991: 10).

With his interest squarely focused on Western Europe, Kozyrev, however, made no mention of the Yugoslav republics. He concluded that regrettably those in the European region such as the German federal states had always had far greater manoeuvring room when it came to forming their policies in addition to their own financial resources. The Soviet republics, on the other hand, had no foreign exchange budget. Therefore, when Russian delegations went abroad, they were obliged to seek foreign currency in the city centre or procure it by 'inconceivable methods' (Razuvaev 1991: 10).

4 Ljubljana and Minsk established the closest contact. This can be seen from a report on L. Peterle's visit to Belarus from 02 to 04 June 1991; an agreement on the opening of diplomatic missions for the republics in Minsk and Ljubljana respectively; and the opening of a Belarus bank set to work in coooperation with not only Slovenia, but also Austria, and Italy. In: Istoriko-diplomaticheskoe upravlenie MID SSSR, Arkhiv vneshney politiki SSSR, Fond 144 3EU, REFERENTURA PO YUGOSLAVII, Opis 52, Delo 6, Papka 124, 110 - POLITICHESKIE VOPROSY, Eks. 1, Ish. 216, 13 June 1991. 


\section{Efforts to Institutionalise Relations}

Roman Kokalj, the head of Slovenijales' Moscow office, the biggest branch office of any Slovenian company in the Soviet Union, was a trailblazer in establishing direct contacts between Slovenian and Soviet diplomatic representatives. He was later appointed an "authorised representative of Slovenia" though not an ambassador. In his memoirs, Kokalj writes about the large Serbian community in Moscow as well as the well-established Serbian lobby, which drew on historical and cultural/literary ties between Russia and Serbia. This community steered the Yugoslav embassy's activities during the disintegration of Yugoslavia and clearly opposed Slovenia's sovereignty:

The Yugoslav embassy in Moscow at first tried to present the process of Slovenia's independence as an internal political issue and then portrayed the already independent Slovenia as the main culprit for the collapse of Yugoslavia and the ensuing armed conflicts in the territory of the former common state (Kokalj 2006: 1).

The main task of the small Slovenian community was to find and establish contacts with influential people who would be sympathetic to Slovenia and, through them, create contacts with the Russian foreign ministry, which had closed its doors to representatives of unrecognised states. However, as Kokalj (2006:5) writes, 'very few people were in favour of Slovenia's sovereignty and the recognition of Slovenia's independence.' At the end of 1990, Slovenian Foreign Minister Dr. Dimitrij Rupel visited Moscow where he was not received by Boris Yeltsin, then still the chairman of the Supreme Soviet of the RSFSR. Rupel then met with USSR Deputy Foreign Minister Y. A. Kvitsinsky, ${ }^{5}$ RSFSR Deputy Foreign Minister B. Kolokolov, USSR Minister of Trade USSR, K. Terekh and E. Bičkauskas and J. Han, who were permanent representatives in Moscow of Lithuania and Estonia respectively. Rupel presented them with the four basic referendum documents: the announcement to voters, the statement of good intent, the referendum law and the document concerning relations with the Council of Europe. The report of the Soviet diplomats drew largely from reports in the Slovenian media, which they described as generally objective and unbiased. They commented especially on the immense success of Slovenian diplomacy after:

the Soviet side stated that the Soviet Union strongly supported the inviolability of Europe's borders, the preservation of the territorial integrity of Yugoslavia and the development of bilateral relations, without excluding dialogue with

5 On 28 December 1991, Rupel also wrote to invite Kvitsinsky to Slovenia. In: Istoriko-diplomaticheskoe upravlenie MID SSSR, Arkhiv vneshney politiki SSSR, Fond 144 3EU, REFERENTURA PO YUGOSLAVII, Opis 52, Delo 7, Papka 125. 110 - POLITICHESKIE VOPROSY, Ish. 76/3EU ot 18 January 1991. 
individual republics, [since] the Slovenian referendum is an 'internal matter of Yugoslavia.' According to D. Rupel, Kvitsinsky 'has in no way denied Slovenia its path to autonomy through a referendum.' [...] The only embarrassment he admittedly faced in Moscow arose in a conversation with the Yugoslav ambassador, M. Vereš. After D. Rupel handed him the referendum documents, the ambassador notified him over the phone a while later that he still thought it was pointless to join $\mathrm{D}$. Rupel in the talks with the Soviet representatives because he would be forced to present views contrary to the Slovenian ones. ${ }^{6}$

Before this, the Slovenian foreign minister paid a courtesy visit to the Yugoslav embassy, where he spoke solely in Slovene, clearly noticing that the others present had great difficulty in understanding him:

Ambassador Vereš sighed loudly, anxiously wringing his hands. Standing behind him was Secretary Dikić, staring at the ceiling and sometimes at me. I had known him from before. The embassy had not hosted such a show for quite a while. The ambassador apologised for not understanding Slovene and Rupel responded that the front gate bore the inscription "Embassy of the SFRY." Hence, the embassy in the Soviet Union also represented Slovenia and the ambassador should also understand its language. Now, a member of Rupel's delegation, Janez Kocjančič intervened, saying that language should unite rather than divide and that there was no need to speak Slovene. Rupel explained to him that it was inappropriate to use English in the common embassy and that he would insist on Slovene (Kokalj 2006: 7-8).

In their efforts to establish contacts with Soviet diplomats and hold talks on Slovenia's recognition, the Slovenes faced yet another problem: finding space for these discussions. The staff members of the representative office of Slovenijales had close and even familial ties with the embassy. A considerable number of diplomats in the foreign ministry had connections with Yugoslav colleagues in Moscow and Belgrade:

On the grounds of secrecy, most meetings were held in the basement of Slovenijales' exhibition hall in Kozitsky Pereulok, Moscow. Had the talks taken place in the embassy building, Belgrade would have learned about them much sooner than Ljubljana. Nor could meetings be held in the foreign ministry building, where, as Deputy Minister Kolokolov told me, many staff members had close personal contacts with colleagues from the Yugoslav embassy. Information

6 Istoriko-diplomaticheskoe upravlenie MID SSSR, Arkhiv vneshney politiki SSSR, Fond 144 3EU, REFERENTURA PO YUGOSLAVII, Opis 52, Delo 7, Papka 125, 170 Voprosy pressy i informatsionno-propagandistskoy raboty. Eks. 1, Ish. 411, 03 January 1991. 
might quickly reach the Federal Secretariat of Foreign Affairs in Belgrade (Kokalj 2006: 9-10).

Others also tried to convince the Soviet side that Slovenia had undertaken the correct course of action. Such persons included President of the Presidency of the Socialist Republic of Slovenia Milan Kučan, Slovenian Assembly President Dr. France Bučar and President of the Slovenian Government Lojze Peterle. In January 1991, the latter wrote to Eduard A. Shevardnadze, who was still obviously acting as Soviet foreign minister despite having resigned from the position on 20 December 1990. In this message, Peterle reported the results of the independence referendum, stressing that Slovenia was obliged to abide by the will of its citizens and prepare all necessary legal provisions to ensure Slovenian independence within six months. ${ }^{7}$

Next, on 18 March 1991, Kučan wrote directly to Soviet President Mikhail Gorbachev, requesting his support and understanding of Slovenia's endeavours and recognition of its independence. Preserved only in translation in the archive, the letter which Y. Girenko, Consul General in Zagreb sent to A. Nikiforov, First Deputy Chief of the Third European Administration of the USSR MFA, included the wording of the resolution on Slovenia's secession from Yugoslavia, which the Slovenian assembly passed on 20 February 1991. As Kučan wrote, the resolution was a clear indication of Slovenia's efforts to find a peaceful solution to the Yugoslav crisis. At the same time, Slovenia believed that it was building a new, independent home - just like the homes that other European nations, small and large, had already built for themselves. ${ }^{8}$

During the Slovenian prime minister's visit to Moscow from 14 to 16 May 1991, Slovenia and the Russian Federation signed the Agreement on Economic, Scientific, Technical and Cultural Cooperation. Nikiforov prepared a diplomatic report from the Soviet consulate-general in Zagreb, drawing largely on responses in the Slovenian media. To the evident satisfaction of the Soviet diplomats, that media praised the visit, and a source quoted Peterle's statement that it was 'the most important and successful of all such visits abroad. ${ }^{\prime 9}$ Rupel had also pointed out the high level of Peterle's dialogue partners and Yeltsin's promise to visit Ljubljana. Nikiforov put it:

7 Istoriko-diplomaticheskoe upravlenie MID SSSR, Arkhiv vneshney politiki SSSR, Fond 144 3EU, REFERENTURA PO YUGOSLAVII, Opis 52, Delo 7, Papka 125. 110 - POLITICHESKIE VOPROSY, Vh. 7-ChP-3EU ot 24 January 1991.

8 Istoriko-diplomaticheskoe upravlenie MID SSSR, Arkhiv vneshney politiki SSSR, Fond 144 3EU, REFERENTURA PO YUGOSLAVII, Opis 52, Delo 6, Papka 124, 103 - Obmen poslaniyami i pismami, Eks. .1, Ish. 112, 27 March 1991.

9 Istoriko-diplomaticheskoe upravlenie MID SSSR, Arkhiv vneshney politiki SSSR, Fond 144 3EU, REFERENTURA PO YUGOSLAVII, Opis 52, Delo 6, Papka 124. 110 - POLITICHESKIE VOPROSY. O slovenskey reaktsii na vizit premier-ministra Slovenii L. Peterle v Moskvu. . 1, Ish. 180, 24 May 1991. 
Another reason why the Slovenes think that the visit may contribute to the republic's greater reputation and weight is because in this way it will strike a balance to the well-known unilateralism of the hitherto markedly pro-Western foreign relations pursued by the Slovenian leadership (only recently, this could be said for Kučan's visits to Austria, Germany and Italy, Peterle's trip to France, and so forth). In this regard, the Slovenian dailies Delo and Dnevnik provide some eloquent comments, clearly illustrating the need to broaden and deepen the cooperation with the Russian Federation, especially after the visit to Moscow proved that Russia not only showed sympathy and understanding [of] Slovenia, but confirmed this with an actual agreement while 'Western politicians did little more than buzz in our ears about the necessity to preserve the united and democratic Yugoslavia.' [...] Major publicity in the republican media was given to I. S. Silaev, who said that 'the Russian leadership follows with great interest the developments in Yugoslavia,' and that he was literally 'rooting for Slovenia' because, as he put it, 'the Russian Federation also aims to ensure autonomy within the framework of the reformed Soviet Union and strives to reconstruct the state on confederative principles.' [...] Yeltsin emphasised that the "historical" agreement (Author's note: This was the first such document to be signed by Russia and Slovenia) was in complete congruence with the process of "sovereignising" the republics. Peterle: 'Regardless of our geographical distance, Russia and Slovenia are on the same wavelength. ${ }^{10}$

At the end of the report, which also touches upon Serbia's press coverage of Peterle's visit to Moscow, Nikiforov observed that the latter had nevertheless prompted different reactions. He illustrated his point with a commentary from Borba (May 18-191991), titled 'Peterle's Secrets,' which 'states with unconcealed jealousy that Slovenia is trying to talk the Russian Federation into supporting its separatist aspirations.' ${ }^{11}$

But this is only one side of the complex story of the forging of SlovenianRussian relations. Slovenia's endeavours were one thing, Belgrade's interests were another and both were situated within a context of maintaining the ratio of powers and interests in the international sphere. Outsiders' opinions about the kind of policy the Soviet Union should pursue towards Yugoslavia were far from what the Slovenes wished for. On 07 February 1991, Soviet Deputy Foreign Minister Kvitsinsky informed the new chief of the Soviet Diplomatic Mission, Alexander A. Bessmertnykh (15 January - 23 August 1991) about a recent statement issued by the United States on 25 January 1991 concerning Yugoslavia and the increasingly volatile situation in Croatia. In that statement, the United States expressed its concern over 'the growing tensions between the Yugoslav

10 Ibid.

11 lbid. 
republics and peoples, and the threaten[ed] escalation of violence. ${ }^{12}$ Kvitsinsky wrote that the United States had showed no interest in abandoning the idea that Commission on Security and Cooperation in Europe (CSCE) participants should issue a joint statement on the situation in Yugoslavia, a position which the deputy Soviet foreign minister condemned as unilateral:

While protecting the 'democratically elected institutions' in Croatia, the United States "fails to notice" the unconstitutionality of armed units raised by their authorities. [...] In the key American formulation, 'the United States supports the democracy and unity in Yugoslavia,' the emphasis is shifting more and more onto 'democracy' at the expense of dwindling support for the integrity of the Yugoslav federation. The Yugoslav side trusts that in our contacts with the United States (and possibly the Federal Republic of Germany) we will do everything in our power to prevent any attempt at internationalising the issue of inter-republican relations. [...] In our opinion, it is possible to comply with the Yugoslav requests and further pursue our efforts in this direction. ${ }^{13}$

The Soviet Union proceeded to express concerns about the weakening of the Yugoslav central government, the dismantling of federal state and socio-political structures, the deepening of the economic crisis and the exacerbation of antagonisms between the republics and peoples. Such antagonisms were further intensified by the ideological divergence of power structures in the Yugoslav republics as well as intensifying religious friction and the growing influence of Islam. According to a Soviet embassy report dated 15 February 1991, over two hundred political parties and movements had sprung up at that time:

In 1990, all republics held multiparty elections which the communists only won in Serbia and Montenegro. The remaining four republics witnessed the rise of "nationalist forces." 14

The loosening of the Yugoslav federation sent a rippling effect across the Balkans, which mobilised nationalist forces in neighbouring states according to the Soviets. The eventual departure of individual republics from Yugoslavia

12 Istoriko-diplomaticheskoe upravlenie MID SSSR, Arkhiv vneshney politiki SSSR, Fond 144 3EU, REFERENTURA PO YUGOSLAVII, Opis 52, Delo 6, Papka 124, 110 - POLITICHESKIE VOPROSI, MID SSSR Upravlenie SShA i Kanadi, Vh. 1050 ot 5. 3. 1991/3EU MID SSSR Vh. 379 ot 7 March 1991.

13 Istoriko-diplomaticheskoe upravlenie MID SSSR, Arkhiv vneshney politiki SSSR, Fond 144 3EU, REFERENTURA PO YUGOSLAVII, Opis 52, Delo 6, Papka 124, 110 - POLITICHESKIE VOPROSY, MID SSSR Upravlenie SShA i Kanadi, Vh. 1050, 5 March 1991/3EU MID SSSR Vh. 379 ot 7 March 1991/ 2357/OS-ns.

14 Istoriko-diplomaticheskoe upravlenie MID SSSR, Arkhiv vneshney politiki SSSR, Fond 144 3EU, REFERENTURA PO YUGOSLAVII, Opis 52, Delo 6, Papka 124, 110 - POLITICHESKIE VOPROSY, O POLOZHENIYE V YUGOSLAVSKOY FEDERATSIII I NASHEY LINIYI V OTNOSHENIYAH SFRYU, Eks. 12, 201/3EU ot 15 February 1991. 
would complicate the situations of national minorities and give rise to the issue of changing borders. The authors of the Soviet report maintained that any change in the current state structure of Yugoslavia would encourage individual regions to seek their own "patrons." The main emphasis was on two factors: the Austro-German one to the northeast of Yugoslavia and the "Islamic" one represented by the rising economic and military power of Turkey, the supporter of Yugoslavia's so-called Muslim belt (Bosnia and Herzegovina, Kosovo and Macedonia)..$^{15}$ None of this was in the interests of the Soviet Union. Put more explicitly, these developments threatened not only to negatively affect perspectives on the general European situation but - most importantly - to harm other multinational states:

The Soviet Union should therefore give its unconditional support to the unity and territorial integrity of Yugoslavia and its stable development, as well as encourage the implementation of democratic changes and government measures to overcome the crisis. [...] We find it of utmost importance not to lose sight of the positive aspects that have accumulated in our recent relations with Yugoslavia. Unlike other Eastern European states, Yugoslavia and its nations have retained the same genuinely amicable attitude towards the Soviet Union. Hence, rather than "making the turn to the West," Eastern Europe continues to remain steadfast in its universal national consensus on the necessity to actively develop relations with the Soviet Union. ${ }^{16}$

The opinions of the Soviet diplomats in Belgrade and Zagreb differed slightly from one another when it came to the situation in Yugoslavia. Reporting on the Resolution on a Peaceful Separation from the Socialist Federal Republic of Yugoslavia (SFRY), which had been adopted by the Slovenian assembly on the night of 20-21 February 1991, P. Zavgorodniy, the first secretary of the Soviet embassy in Belgrade, expressed his confidence that this was merely another loud statement by the Slovenes rather than an actual step towards Slovenia's secession. ${ }^{17}$ The diplomat admitted that Slovenia had passed all required legal provisions to attain its independence, but maintained that the Slovenes were 'sobered' by economic difficulties although the politicians had shown less restraint than the economists. Peterle and Rupel had not garnered the desired international support; Zavgorodniy considered Pučnik and Bučar 'radical' for demanding Slovenia's immediate separation from Yugoslavia, and he opposed

15 Ibid.

16 Ibid.

17 Istoriko-diplomaticheskoe upravlenie MID SSSR, Arkhiv vneshney politiki SSSR, Fond 144 3EU, REFERENTURA PO YUGOSLAVII, Opis 52, Delo 9, Papka 125, 710, 1 SPRAVKI PO POLITICHESKIM VOPROSAM, Eks. 1, Ish. 119, 28 February 1991, O nekotorikh deystviyakh rukovodstva Slovenii pri obespecheniyu suvereniteta i nezavisimosti respubliki (Informatsiya). 
them to the more 'realistic' Kučan and Drnovšek. Nonetheless, the leadership of the republic was forced to consider the increasingly radicalised positions within a population encouraged by extremist politicians. ${ }^{18}$

In contrast, Nikiforov, the attaché at the consulate-general in Zagreb, pointed to the intensifying attempts of the 'northern' republics to internationalise the Yugoslav crisis. Slovenia and Croatia were stepping up their international activity: examples ranged from Tuđman and Peterle's participation in the high-profile Franz Josef Strauss forum in November 1990 in Bavaria to Tudman and Drnovšek's presence at the February 1991 economic forum in Davos and at a round table with a massive turnout in Vienna on 24 March 1991. Nikiforov concluded that Slovenia and Croatia had mostly been intensifying connections with their neighbours such as Austria and Italy along with Germany. The changes in their official positions were quite remarkable. The diplomat also provided an interesting assessment of Slovenia's not-always-successful efforts to keep its international activities in step with those of Croatia. After a series of failed attempts to win international recognition of Slovenia and in the face of opposition criticism of the failure to provide a clear programme, Foreign Minister Rupel was now taking a more cautious line. Kučan had made the most successful visits, travelling to Vienna (13-14 March 1991) as well as Stuttgart and Bonn (19-20 March 1991). On the occasion of his visit, Austrian Foreign Minister A. Mock had stated that Austria would react swiftly to Slovenia's declaration of independence, to which Rupel responded with a quote from German Foreign Minister H. D. Genscher: 'Germany cannot push Yugoslavia towards disintegration, but it will understand Slovenia's secession. ${ }^{19}$

Nikiforov also noticed that Slovenia had undertaken a new two-prong strategy: on the one hand, it was developing a policy of appointing businessmen, for example, from Slovenijales and Ljubljanska banka as the republic's authorised representatives abroad. On the other hand, it was trying to convince prominent foreign figures that Slovenian independence was legitimate and just. In view of the scathing criticism the Belgrade meeting of 09 March 1991 had attracted in the international community, Nikiforov took note of growing sympathies towards Croatia and Slovenia. This trend, in his opinion, would continue in the future. ${ }^{20}$

In the early days of June 1991, Belgrade received a visit from Soviet Prime Minister Valentin Pavlov, who confirmed to the Pravda newspaper that Moscow's position remained unchanged. Its main dialogue partner continued to be the Yugoslav federation:

18 Ibid.

19 Ibid.

20 Istoriko-diplomaticheskoe upravlenie MID SSSR, Arkhiv vneshney politiki SSSR, Fond 144 3EU, REFERENTURA PO YUGOSLAVII, Opis 52, Delo 9, Papka 125, 710, Tom 1, SPRAVKI PO POLITICHESKIM VOPROSAM, Eks. 1, Ish. 118, 27 March 1991, Novye tendentsii po vneshnepoliticheskoy aktivnosti Khorvatii i Slovenii. 
I would very much like to emphasise the special relation that our country has towards Yugoslavia. We are tied by good old historical tradition. We understand very well the current predicament of Yugoslavia. And our opinion is well-known: we extend our solidarity to the forces which endeavour to preserve a strong state of unity and freedom. We express our hope that the processes that are ongoing today will reach a successful conclusion, without any external interference (quoted in Fadeyev 1991: 5).

\section{The Declaration of Slovenian Independence}

While they followed the process of Yugoslavia's disintegration, the Soviet diplomats wrote detailed reports on debates about the future arrangement of the federation and the confrontation between two diametrically opposed concepts: federalism and confederacy. ${ }^{21}$ The Zagreb consul, V. Marusin warned that differences in opinion - with the Presidency of the SFRY, the Yugoslav People's Army (JNA) and Slobodan Milošević categorically rejecting the idea of a confederation - had led Slovenia and Croatia to hold talks that were primarily bilateral with the delegations of other republics. The deteriorating situation in Croatia in the spring of 1991 prompted Slovenia's leadership to step up its preparations for independence. In doing so, Demos resorted to more radical measures than Kučan, fearing that growing tensions in Yugoslavia and in Serbian-Croatian relations might thwart their independence plans. Kučan, on the other hand, tried to prevent Slovenia from being forced into unilateral secession. While Prime Minister Peterle claimed that the 'issue of independence will be resolved in June,' President Kučan explained the Resolution on Separation as though it were not a matter of secession..$^{22}$ Slovenia and Croatia adamantly promoted the concept of a union of sovereign states: 'With both sides failing to reach an agreement on the future of Yugoslavia, the crisis is taking on a protracted nature and may stir up much more than dissent among the republics. It is quite possible to imagine that the intransigent approach of the Serbian leadership to resolving the deadlock may prompt Slovenia and Croatia to take steps that will eventually lead to the disintegration of Yugoslavia. ${ }^{23}$

21 Istoriko-diplomaticheskoe upravlenie MID SSSR, Arkhiv vneshney politiki SSSR, Fond 144 3EU, REFERENTURA PO YUGOSLAVII, Opis 52, Delo 9, Papka 125, 710, Tom 1, SPRAVKI PO POLITICHESKIM VOPROSAM, Eks. 1, Ish. 151, 24 April 1991, O pozitsii slovenskogo i khorvatskogo rukovodstva na peregovorah o pereustroystve Yugoslavii (Informatsiya).

22 lbid.

23 Istoriko-diplomaticheskoe upravlenie MID SSSR, Arkhiv vneshney politiki SSSR, Fond 144 3EU, REFERENTURA PO YUGOSLAVII, Opis 52, Delo 9, Papka 125, 710, Tom 1, SPRAVKI PO POLITICHESKIM VOPROSAM, Eks. 1, Ish. 172, 16 May 1991, O podkhodakh Khorvatii i Slovenii k razresheniyu yugoslavskogo krizisa i pereustroystvu Yugoslavii (Informatsiya). 
Still, on the eve of Slovenia's independence, diplomatic reports continued to present different opinions about whether such a step was at all possible. Whereas the diplomats at the Belgrade embassy were sceptical at best, those at the Zagreb consulate-general held, albeit with some reservations, that independence was a probable outcome. The Zagreb attaché Nikiforov, thus, stated in his May report that Slovenia would secede by the designated date (26 June 1991), no matter what it called this step - secession, separation or something else. ${ }^{24}$ However, he argued that owing to internal and external obstacles, the Slovenian action would only have a normative-declarative character. The internal obstacles mostly had to do with the economic predicament; the major external ones included concerns in the international community over the possible aftermath in the rest of Yugoslavia. Some members of the Slovenian government, Nikiforov wrote, were not willing to venture a quick secession that might prompt a decline in citizens' living standard. According to some assessments, that standard would drop by 30 percent:

Therefore, an increasing number of voices have been raised in Slovenia against the immediate termination of all ties with the Yugoslav federation, for which it would not find alternatives any time soon. All the more so because once it secedes, the Slovenian republic will undoubtedly remain in international isolation for some time..$^{25}$

According to Nikiforov, the statement that the Slovenian assembly submitted to the federal assembly on 08 May 1991 demonstrated a 'certain change in the Slovenian position. Namely, the document not only announces that the republic will declare its state independence on 26 June, but also clearly expresses its willingness to cooperate in inter-republican negotiations on all outstanding issues, including those that may arise from the separation process. ${ }^{26}$ Peterle, Rupel and others were equally aware of the harmful implications of breaking ties, as is evident from their statements that 'this is a smooth, peaceful secession, based on negotiations' ${ }^{27}$ and that Slovenia must first gain recognition within Yugoslavia. At the same time, the republic seemed less radical when it came to the introduction of its own currency, passports and armed forces. Yugoslav passports and the dinar would remain valid during the transition period and Slovenia would continue to fund the Yugoslav People's Army (JNA). In other words, as Nikiforov

24 Istoriko-diplomaticheskoe upravlenie MID SSSR, Arkhiv vneshney politiki SSSR, Fond 144 3EU, REFERENTURA PO YUGOSLAVII, Opis 52, Delo 9, Papka 125, 710, Tom 1, SPRAVKI PO POLITICHESKIM VOPROSAM, Eks. 1, Ish. 177, 16 May 1991, K voprosu o perspektivah vozmozhnogo vyhoda Slovenii iz sostava SFRYu (Kratkaya spravka).

25 Ibid.

26 Ibid.

27 Ibid. 
writes, the transition period would actually commence - rather than end - with the declaration of independence, with no knowing how long this period might last or how successful the negotiations with Belgrade would be. ${ }^{28}$

Nevertheless, the entanglement in the Yugoslav presidency hampered talks with the central government. Slovenia and Croatia reacted harshly to the failure to elect Stipe Mesić as president of the state collective governing body - according to the rotation principle, he should have assumed that position on 15 May 1991. The Zagreb consul Marusin noted that even high-level federal politicians such as Marković and Lončar unofficially admitted that the Serbian leadership had made a mistake by not electing Mesić. ${ }^{29}$ Slovenia and Croatia took this as a clear indication that their plans for the future arrangement of Yugoslavia had become even less feasible and they blamed Serbia for the situation. Owing to the collective state leadership's inability to act, both republics now directed their efforts at preventing the activation of armed forces. Slovenia and Croatia supported Federal Prime Minister Marković, fearing that his removal would allow Serbia to take the initiative and realise its own plans with the assistance of the army. ${ }^{30}$

The presidential gridlock also left Yugoslavia in a dead-end when it came to international relations. At a Pentagon session in Bologna, Slovenian Foreign Minister Rupel stated that Slovenia could not be fully involved in governing the Yugoslav state, which it perceived simultaneously as a threat. He proposed thating a "goodwill mission" be formed within the Pentagon to assist withthe drawing up proposals for negotiations on the separation of the Yugoslav republics. ${ }^{31}$ Consul Marusin concluded that the Brussels stance on Slovenia and Croatia had even greater consequence than that of the United States, but that certain unnamed Western states were changing their positions. In any event, Slovenia and Croatia felt confident enough to launch an independent defence against the JNA, and the consul noted that according to some rumours, they were relying on outside support in the form of NATO's rapid reaction through force. This is the first reference to the NATO alliance in the diplomatic sources. ${ }^{32}$

The Soviet Union reacted to the declaration of Slovenian and Croatian independence by promptly issuing three statements. The foreign ministry drew up

28 Ibid.

29 Istoriko-diplomaticheskoe upravlenie MID SSSR, Arkhiv vneshney politiki SSSR, Fond 144 3EU, REFERENTURA PO YUGOSLAVII, Opis 52, Delo 9, Papka 125, 710, 1, SPRAVKI PO POLITICHESKIM VOPROSAM, Eks. 1, Ish. 172, 16 May 1991, O podhodah Khorvatii i Slovenii k razresheniyu yugoslavskogo krizisa i pereustroystvu Yugoslavii (Informatsiya).

30 Istoriko- diplomaticheskoe upravlenie MID SSSR, Arkhiv vneshney politiki SSSR, Fond 144 3EU, REFERENTURA PO YUGOSLAVII, Opis 52, Delo 9, Papka 125, 710, Tom 1, SPRAVKI PO POLITICHESKIM VOPROSAM, Eks. 1, Ish. 200, 29 May 1991, O novyh podhodah Khorvatii i Slovenii k resheniyu yugoslavskogo krizisa (Informatsiya).

31 lbid.

32 lbid. 
two statements condemning the steps taken by Ljubljana and Zagreb; the first of these was dated 26 June 1991:

The Soviet Union continues to extend its unwavering support for the unity and territorial integrity of Yugoslavia, the stability of its borders, including the internal ones, the right of the Yugoslav peoples to determine their own future, as well as support for the federal authorities, which strive to preserve the Yugoslav state (Gus'kova 1993: 56).

Three days later, the ministry issued a second statement in response to actions by the JNA and the armed conflict that had erupted in Slovenia. This time it no longer referred to several peoples but a single Yugoslav nation:

The dramatic developments in the SFRY are causing grave concern. A united, independent Yugoslavia is of utmost importance for stability in the Balkans and Europe more generally. It is imperative for every constructive European and international political domain to offer its assistance and support to the Yugoslav nation in this difficult moment. The Soviet Union extends its sympathies and solidarity to the friendly Yugoslavia. It welcomes the call by the Federal Executive Council of the SFRY for the political forces in the state to issue a three-month moratorium on the implementation of all decisions taken with regard to the separation, break-up, the change in the regime of external and internal borders...(Gus'kova 1993: 57-58).

The Soviet foreign ministry also called on the international community to support the Yugoslav government and ensure conditions for the preservation of the territorial integrity of Yugoslavia. Finally, it returned to the "peoples": 'we must help the peoples of Yugoslavia to provide a solid future for their state in a democratic and peaceful manner' (Gus'kova 1993: 58).

On 28 June 1991, a special statement was also issued by the parliament of the Russian Republic, the Supreme Soviet of the Russian Federation, whose leadership had been assumed by Ruslan Khasbulatov after the previous chair Boris Yeltsinwon the presidential elections on 12 June. This statement was brief and laconic and is therefore presented in its entirety:

The Supreme Soviet of the RSFSR expresses its concern over the developments in the friendly Yugoslavia and deplores the fact that the civil conflict has exacted a human toll. We firmly believe that the parties in the conflict will find a solution to the predicament through negotiation and without resorting to the use of force (Gus'kova 1993: 57). 
The most striking aspect of this statement is its impartiality. The members of Russian parliament refrained from condemning individual Yugoslav republics. They were later embroiled in bitter debates concerning Russia's policy toward the crisis in Yugoslavia and, with the exception of the Liberals and Democratic Reformists, they all parted ways with President Yeltsin on internal political issues. Yeltsin, in turn, also took leave of his former ally Khasbulatov. Nevertheless, according to Gryzunov and Romanenko, the conciliatory tone in the aforementioned statement had less to do with Yugoslavia than it did with its authors' own fate and that of the Soviet Union:

The Russian leadership viewed the Slovenian and Croatian efforts towards complete political self-determination and sovereignty as a confirmation of the anti-centralist and disintegration tendencies in the territory of the Soviet Union (Gryzunov - Romanenko 2012: 11-12).

\section{War}

As far as the international political sphere's stance towards Yugoslavia is concerned, the war in Slovenia brought many changes. The head of the Third European Administration of the USSR MFA, Senkevich concluded his report to Soviet Foreign Minister Bessmertnykh as follows:

After the chief of the general staff of the JNA, Colonel General Adžić, stated on 02 July that the army would 'win at all costs,' a certain danger appeared that federal organisations would lose control over the army, which would annul the agreements that had been achieved. ${ }^{33}$

According to Senkevich, the Yugoslav federation still had support from the international community, but at the same time, Germany, Austria, Hungary and others were beginning to take positions that would enable them to collaborate with republics leaving the federation in the future. In Europe and the United States, far-right political parties were starting to exert pressure on governments to recognise Slovenian and Croatian independence. Step by step, the two republics were fulfilling their goals and so trying to achieve a broad internationalisation of the "Yugoslav question" and - aside from CSCE mechanisms - also involve the UN Security Council. There was some evidence to indicate that the West had put pressure on Mesić in that direction. According to British information sources, in a letter received in London on 02 July, Mesić appealed to the

33 Istoriko-diplomaticheskoe upravlenie MID SSSR, Arkhiv vneshney politiki SSSR, Fond 144 3EU, REFERENTURA PO YUGOSLAVII, Opis 52, Delo 6, Papka 124, 110 - POLITICHESKIE VOPROSY, 819/3EU, 04 July 1991. 
international community to take concrete steps towards achieving peace and normalcy in Yugoslavia. The letter stated that 'an overthrow [has] happened in Yugoslavia and that the JNA is out of control. ${ }^{34}$

After the Brioni Declaration was signed, Soviet Foreign Minister Kvitsinsky's deputy and delegate visited Belgrade, Zagreb and Ljubljana (from 06 to 08 July 1991) together with a negotiating mandate. According to the records of the Soviet diplomat in Zagreb, A. Nikiforov, the Slovenian and Croatian media understood Kvitsinsky's visit as a sign of the strengthening of Soviet politics in Yugoslavia and of the Soviet presence more generally in this area. They put special emphasis on Soviet support for the unity and territorial integrity of Yugoslavia and the inviolability of its borders, including internal ones. Neither the Soviet Union nor Europe wanted to create a precedent for separatism that could trigger similar tendencies in the Soviet Union. ${ }^{35}$ Nevertheless, Nikiforov pointed out an important detail that was becoming more and more evident in the Soviet Union: this was the strong Slovenian and Croatian conviction that Soviet support for Yugoslavia's territorial integrity in fact translated into direct support for Serbia and a passion for the idea of Greater Serbia. In the northwest of Yugoslavia, that kind of understanding fostered a growing and strengthening opposition to the Soviet Union. The Zagreb attaché mentioned that calls and letters to the consulate-general had conveyed Croatian citizens' complaints about Soviet foreign policy; the complaints even identified traces of support for the Chetniks. ${ }^{36}$ Based at least on the available sources, the first diplomatic warning that the Soviet Union would need to the change its attitude to the Yugoslav reality also came from Zagreb. On 16 July 1991, Consul General Girenko sent a detailed message to Deputy Soviet Foreign Minister Kvitsinsky in Moscow. This text expressed views that were diametrically opposed to Soviet foreign policy practices at the time:

The intoxication of nationalism has blinded the leaders of the republics so much that it will be hard to reach an agreement without international help. [...] Hence, there is no point in insisting on opposition to internationalisation, rather, we need to strive for a policy, and a political policy in particular, that won't allow for harsh interference in Yugoslavia's internal affairs and the imposing of foreign will. [...] It would make sense to soften our intransigence,

34 Ibid.

35 Istoriko-diplomaticheskoe upravlenie MID SSSR, Arkhiv vneshney politiki SSSR, Fond 144 3EU, REFERENTURA PO YUGOSLAVII, Opis 52, Delo 7, Papka 125, 170 Voprosy pressy i informatsionno-propagandistskoy raboty, Annotatsiya materiyalov yugoslavskoy pechaty o prebivanii spetsial'nogo predstavitelya Prezidenta SSSR Yu. A. Kvitsinskogo v SFRYu 6-9 yulya 1991 g. (10 July 1991. 850/3EU) (posol'stvo), Eks. 1, Ish. 259, 11 July 1991 (attashe Genkonsul'stva A. Nikiforov).

36 Ibid. 
also having regard to the possibility of discussing the Yugoslav crisis in the UN Security Council. ${ }^{37}$

Referring to matters beyond support for internationalisation, Girenko also proposed that given the situation, the withdrawal of support for Yugoslavia's territorial integrity also be discussed: 'The most delicate element of the inevitable correction of our stance on the Yugoslav crisis is apparently our thesis about maintaining Yugoslavia's unity and wholeness.' 38 The consul-general believed that the support extended by Germany and other Western states to the separatist leaders of Slovenia and Croatia stemmed from these countries' self-interest and self-serving agendas. Nevertheless, he argued that:

The clear list of external factors that would support Yugoslavia's wholeness only ignites violence on the side of the JNA and strengthens the tendencies of the greater-Serbia hegemony. [...] Our stance that supports the unity of Yugoslavia is being linked with the patronage of the Russophile orthodox Serbia, which is in turn being accused of making efforts to turn Yugoslavia into Serboslavia. It seems that - given the circumstances - it would be strategically smarter to combine the idea of supporting Yugoslavia's unity and territorial integrity with greater flexibility, which would enable us to distance ourselves from the efforts of those who wish to frame us as supporting the idea of greater-Serbia or even neo-chetnik ideas, which are continuing to grow stronger, also in response to the revival of Croatia-centric tendencies. ${ }^{39}$

Girenko concluded that the Yugoslavs were relinquishing the idea of Yugoslavism, which they considered to be one 'not properly reinforced in the course of history and something that had been artificially forced upon people by Yugoslavia's Communist Party. ${ }^{40}$ The consul had noticed a certain degree of nostalgia for some former states as well as the struggles of Western states (Germany, Italy, and France) to create spheres of interest in areas where they had formerly ruled Balkan territory - that is, before World War II. In Croatia, the idea of a 50:50 division was gaining strength under a plan in which Serbia would become part of the Soviet-influenced zone and Slovenia and Croatia would be part of the Western zone. The opposition to the Soviet Union was strengthened by statements like those made by Minister Yazov and President Gorbachev in Kiev' it emphasised their opposition to the break-up of Yugoslavia. In Slovenia and

37 Istoriko-diplomaticheskoe upravlenie MID SSSR, Arkhiv vneshney politiki SSSR, Fond 144 3EU, REFERENTURA PO YUGOSLAVII, Opis 52, Delo 6, Papka 124, 110 - POLITICHESKIE VOPROSY, 3EU Vh. 2387, 26 July 1991

38 Ibid.

39 Ibid.

40 lbid. 
Croatia, such statements were understood as an expression of support for the idea of Greater Serbia.

Along with stressing the importance of the permanence of external borders under the Helsinki documents and the Paris Treaty, and in order to support a peaceful, democratic way of solving the Yugoslav crisis, we would also need to take a turn and introduce a thesis about the Soviet Union - in line with its striving towards the de-ideologisation of state-to-state relations - and its lack of support for any of the Yugoslav republics in either the ideological, religious or any other sense. ${ }^{41}$

Girenko considered it sensible to avert the connections between the Soviet Union and the Chetniks. This was, in his words, something that the Croatian and Slovenian publicity channels had achieved. The Soviet Union could not support a movement that collaborated with fascists. ${ }^{42}$

Meanwhile, Yugoslavia continued to strengthen its relations with the Soviet Union. Ante Marković and his delegation visited Moscow on 01 August 1991 and informed the Soviet side about the situation in the country as well as the steps taken by the federal government to ease tensions and find a way out of the crisis. Marković thanked the Soviet government for its understanding and support:

The prime minister confirmed the Soviet Union's stance concerning its support for the territorial integrity of Yugoslavia. Moreover, it was pointed out that the Soviet Union was inclined to create the kind of internal and external conditions that would enable the Yugoslav peoples to themselves find a peaceful, democratic and constitutional way of solving the question of future political arrangements. The parties agreed that international efforts to stabilise Yugoslav conditions could not be contrary to the principles of non-intervention in internal matters. ${ }^{43}$

At this point, however, the Soviet Union was mostly dealing with its own problems. A project called the Union of Sovereign States backed by President Gorbachev had stirred up many heated debates, and at the same time, the Soviet republics were starting to demand greater independence; the situation was similar to the one in Yugoslavia. The unsuccessful coup from 19 and 22 August 1991 in which the State Committee on the State of Emergency took control while President Gorbachev was held in Crimea, also caused gradual changes in foreign policies. Comparing the responses of Slovenia and Croatia to the August

41 Ibid.

42 lbid.

43 TASS: Sovetsko-yugoslavski preregovori. Izvestiya (183), 02 July 1991: 4. 
action, historian Sergey Romanenko concludes that Slovenia expressed interest, but was quite reserved and considered this to be a case of "foreign politics." Slovenian sources generally kept silent about the bilateral relations between the Soviet Union and Yugoslavia and the influence of the August coup on Slovenian politics (Romanenko 2011: 980). Romanenko sees this 'reserve' as part of the final Slovenian decision to leave Yugoslavia as well as its choice to head away from the East and move more distinctly towards the West:

According to public polls, public perceptions did not reveal a lot of sympathy or interest for Russia. What came up was a negative view of the needs of Slovenia and Slovenes among the Moscow political elite, which was based on a complete lack of understanding of the situation in Yugoslavia. The Slovenian politicians did not give, or only very rarely (and especially never publically) gave opinions or estimates about the events in Moscow. Taking all that into account, it is clear that Ljubljana had no intention of supporting the "putschists," whose victory would put the only just surfacing Slovene state in a troubling position (Romanenko 2011: 788).

The Croatian response was different. President Franjo Tuđman condemned the coup and expressed his support to the presidents of the Soviet Union and Russia. Because of his nationalistic-state interests, he, thus, reacted in a way that was diametrically opposed to the Serbian administration, which supported the putschists and the arrest of President Gorbachev (Romanenko 2011: 787). At the same time, diplomatic sources reveal that the Slovenian administration did, in fact, express an opinion. Slovenian Foreign Minister Rupel told the Soviet consul-general:

Don't be surprised that the Slovenian administration viewed the recent events in the Soviet Union with great concern; we are sceptical about anything that involves armed forces. Hence, our reaction was fairly negative. We do not make any long-term inferences. We will do that only after we get more precise information from the Soviet Union and after talking to Germany, where I am flying in an hour, and after the talks with Italy, Hungary, Austria, our neighbours with which the Slovenian government is trying to coordinate its foreign policy goals. To be honest, if we look retrospectively at the connections between the Soviet Union and Yugoslav governments (the visit of V. S. Pavlov in Belgrade, A. Marković's trip to Moscow), we see them in a somewhat different light today, for we would not want to have such destabilised conditions in Yugoslavia as we witnessed in the Soviet Union. The development of connections with the Soviet Union and its republics is of extreme importance to the Slovenian government, so the government is interested in continuing and deepening these 
relations. We wish the Soviet Union, which is a key player in world politics, a lot of success in solving its growing internal issues. ${ }^{44}$

President Kučan and Prime Minister Peterle sent separate telegrams to Moscow as early as 22 August 1991 as soon as it became obvious that the coup had not succeeded. Kučan wrote to Russian President Yeltsin while Peterle congratulated Yeltsin as well as Silaev, the Prime Minister of the RSFSR. Minister Rupel did the same and sent a letter on 30 August 1991 to the Boris Pankin, the new Soviet foreign minister, who had been appointed two days prior. Rupel expressed his satisfaction at the fact that the coup had failed:

It is essential for us that the principle of national self-determination won over other outdated principles that can rule a nation; by this, I refer to the Eastern bloc-based principles and ways of thinking that defined the relations between nations and states as well as the fact that many states had already confirmed their understanding of new values by expressing their support for some former Soviet Baltic states - Latvia, Lithuania and Estonia - in their struggle for freedom and independence. ${ }^{45}$

The Slovenian foreign minister concluded that deplorably the situation in Yugoslavia was becoming more and more serious. He used the opportunity to stress his wish for the acknowledgement of Slovenia's independence:

The war in Croatia, which is being fought by Serbian nationalists backed by the JNA, is becoming a symbol of totalitarianism and of the Dark Ages. The government of the Republic of Slovenia turns to your government once again with this plea to acknowledge Slovenia as a sovereign and independent European country. ${ }^{46}$

On 09 September 1991, the letter was apparently delivered to Minister Pankin by ambassador Yuri Derjabin. The latter added a supplementary letter to the English translation of the Slovenian telefax in which he advised:

Taking into account the fact that the position of the Soviet Union with regard to the Yugoslav crisis was clearly explained to the Yugoslav government as well as to Slovenian leaders, I think it best to leave D. Rupel's letter unanswered.

44 Istoriko-diplomaticheskoe upravlenie MID SSSR, Arkhiv vneshney politiki SSSR, Fond 144 3EU, REFERENTURA PO YUGOSLAVII, Opis 52, Delo 6, Papka 124, 110 - POLITICHESKIE VOPROSY, O REAKTSII V KHORVATII I SLOVENII NA PROVAL GOSUDARSTVENNOGO PEREVOROTA V SSSR, Eks. 1, Ish. 332, 28 August 1991.

45 Ibid.

46 lbid. 
We can return to the question of Slovenia's independence at the end of the moratorium on declaring this republic's independence and when we get hold of the results that the CSCE Peace Conference on Yugoslavia brings. This is, in fact, the position of the vast majority of countries-as members of European process. ${ }^{47}$

Despite the negative stance on recognition, the general tone had nonetheless changed somewhat. Moscow decided to wait until the end of the moratorium, and in a September statement from the Soviet foreign minister, we cannot detect any sign of reference to Yugoslavia's unity and territorial integrity; what is foregrounded rather is a deep concern regarding the war in the area, violence and the victims of war:

Our call to cease fire, to fulfil the decisions that the government proper made on 02 September of the same year, to follow the CSCE's recommendations is directed to all the federal structures that are directly responsible for the fates of individual republics and nations in Yugoslavia. We ask the Yugoslav People's Army to hold back and be aware of its responsibility since a lot depends on it. We are turning to the Croatian leadership with a request to continue peaceful dialogues and not resort to ultimatums. We ask Serbia to contribute to a cease-fire at this tragic moment. We are strongly convinced that the only way to solve Yugoslavia's problems is through fair negotiating processes, patient dialogue that seeks out sensible solutions and new ways of coexisting and cooperating in joint economic and legal spaces and maintaining historically legitimised connections. ${ }^{48}$

The change in Soviet views was apparently related to the appointment of the new foreign minister, Boris Pankin (28 August - 14 November 1991). The available diplomatic sources are quiet on this point, but Pankin's own 1993 memoirs are vocal about it even if they touch more on relationships at the foreign affairs ministry than on foreign policy as such. In particular, Pankin wanted to eliminate "hard line" followers at the foreign affairs ministry and as early as the day of his appointment, he fired the first assistant to former foreign minister J. Kvitsinsky, the Soviet mediator in the Yugoslav crisis. At the same time, the foreign affairs ministry launched an initiative to send an intermediary mission of the Soviet Union in Yugoslavia. On 12 September 1991, Gorbachev welcomed Vatican State Secretary Archbishop Jean-Louis Touran. The special envoy of Pope John Paul II put in a request to Gorbachev for 'the Soviet Union to exert additional influence on Serbia' (Romanenko 2011: 790). In the Vatican's opin-

47 Ibid.

48 Iz zayavleniya MID SSSR. Izvestiya (222), 17 September 1991: 5.

POLITICS IN CENTRAL EUROPE 11 (2015) 2 
ion - endorsed by Gorbachev - the most important thing was to stop the war. The Soviet president's foreign policy adviser, Anatoly Chernyaev did not agree with the proposal that the president should host Milošević and Tuđman. He felt ignored and wrote in his diary:

Pankin could not explain why he involved M.S. [Mikhail Sergeyevich Gorbachev] in this matter. The first world leader who gives his blessing to Croatia's "leaving" Yugoslavia? To talk Serbia and Croatia into peaceful...? Ridiculous! As if we didn't have Chechens, Ingush people, Ossetians, Armenians, etc., peoples and places where reconciliation is essential. This is once again not politics but only rhetoric. M.S. is apparently dealing with this in order to create an impression that he is taking part in "real world politics" (Chernyaev 2008: 998).

On 07 October 1991, Gorbachev wrote an appeal to the Yugoslav administration - along with a similar letter to the Croatian President Tuđman (Romanenko 2011: 791) - in which he also stressed that

there is proof that in the next few hours, attacks are going to be launched on large industrial centres and even on Croatia's capital, Zagreb. Such an escalation of attacks would result in numerous victims and tremendous material damage, and the crisis in Yugoslavia would acquire a new dimension, one even more dangerous than was previously recorded. This would undoubtedly bring immediate and harsh condemnation and appropriate responses from around the globe. [...] In these troublesome times, the Soviet leadership turns to the Yugoslav leadership and the leadership of the Yugoslav People's Army and makes a strict appeal to take maximum responsibility and show restraint, so that the attacks do not escalate but change into unconditional and total respect of the cease-fire (Gus'kova 1993: 63).

Gorbachev's appeal came as a big surprise both in the Soviet Union and in Yugoslavia:

Among staff members of the Soviet Embassy, the reaction to the appeal was a certain lack of understanding, to say the least. Serbian circles were simply shocked. Our president only appealed to one side to cease fire - the Serbian army. As if Croatia had respected the conditions of the cease-fire (Gorlov 1991: 3).

Accepting Gorbachev's invitation, Slobodan Milošević and Franjo Tuđman arrived in Moscow on 15 October 1991. The newspaper Izvestiya commented on the intermediaries' peace mission with great enthusiasm: 'Mikhail Gorbachev, displaying top-notch diplomatic skills, managed to achieve that which only yesterday morning seemed highly unlikely' (Yusin 1991: 1). Chernyaev, however, 
went back on his words after the meeting when it was not immediately clear what the long-term effect of the talks would be. He was not optimistic and, in fact, it emerged soon after that none of the agreements had led to anything concrete; they had led to nothing at all. Gorbachev's mediation attempts received negative reviews, both from his contemporaries and subsequently from historians and historiographers:

The unsuccessful diplomatic mission of Gorbachev, who invited the leaders of Serbia and Croatia to have pancakes with him, was easy to predict as Moscow does not have the means to successfully influence Yugoslavia's situation over the long term; a single action could not solve the problem. The CSCE's system has obstructed the eternal search for an oftentimes unattainable consensus. As far as the main mediator - the European Community - is concerned: it totally missed its opportunity because it was caught up in ingrained stereotypes and other strategic games. All of a sudden, everyone in Brussels collectively sees the reality clearly: when the initial idea of a Yugoslav federation (which would also have meant recognition of Slovenia and Croatia) was rejected, Europe did not allow for UN flags to be planted on Balkan soil. Of course, we could not have talked about an operation like "Operation Desert Storm," but the "blue helmets" cordons might have prevented the bloodshed. However, Europe's rigid kind of reasoning has its own logic. When in the capitals of the "Old world" they wrote "Yugoslavia," they had the "Soviet Union" in mind. The wish to ensure there was no precedent for border-closing blurred [the discovery] of a healthy way of dealing with a bloody crisis. It obstructed the search for any kind of compromise besides one involving maintaining the status quo. In order to maintain stability, Moscow, like Brussels, wanted to sacrifice the ambitions of the Yugoslav republics. But the complete opposite happened: 'European constructions will be under attack for many years' (Gus'kova 1993: 452-453).

The views here concerning the European Community's opposition to blue helmets may be challenged since as far as international peace units were concerned, the Soviet Union agreed with Belgrade's stance that foreign units would amount to interference with the country's internal affairs. The Soviet Union also voted in line with this view in the UN Security Council; this is noted in the above-mentioned consul-general report on changes in Soviet policies towards Yugoslavia in July 1991. Although Gorbachev continued to try to preserve Yugoslavia's territorial integrity, some believe that it was this unsuccessful mediation with Milošević and Tuđman that ended the era of Soviet support for Yugoslavia's unity. 


\section{International Recognition of Slovenia}

Following Croatia, which recognised Slovenia's independence on 26 June 1991, the first states to do likewise were Lithuania on 30 July 1991 (having officially re-established its own independence on 11 March 1991) and Georgia on 14 August 1991 (having declared its independence from the Soviet Union on 09 April 1991). All four states were in a similar position: despite having declared their independence, they had to wait for official recognition - for Slovenia and Croatia, this was due to the moratorium and even its expiry did not bring immediate international recognition - while the former Soviet Republics had to wait for the dissolution of the Soviet Union in December 1991.

According to media reports, Lithuania has officially announced its recognition of Slovenian and Croatian independence. The recognition can have no international legal consequences since Lithuania itself is not a separate and international legal entity. In terms of politics, the decision of the Lithuanian government undermines the efforts of the international community to resolve the Yugoslav crisis in accordance with its constitution through the peaceful dialogue of all parties concerned and within the territorial integrity of Yugoslavia. ${ }^{49}$

Responding to the Lithuanian government decision, Slovenian president Milan Kučan stated in an interview with the weekly Novoe vremya in early August:

We appreciate Lithuania's decision as a gesture of solidarity. Slovenia would not, however, want this to have adverse effects on our relations with the Soviet Union. Regardless of what fate the Soviet Federation faces in the future, we are as ever interested in cooperation with all the nations within your state. ${ }^{50}$

Croatia, Lithuania and Georgia were followed by Latvia (28 August 1991), Estonia (25 September 1991) and Ukraine (12 December 1991). According to Roman Kokalj (2006: 12), Ukraine quickly determined that Slovenia did not want to be in conflict with anyone within Yugoslavia; Ukraine's swift decision to recognise Slovenian independence therefore came as no surprise. Looking for an intermediary in Ukraine and one with connections at the foreign affairs ministry in Kiev, Kokalj found the right man in Alexander Slinko, a former official at the Soviet embassy in Belgrade and the Soviet consulate-general in Zagreb. Slinko was retired and happy to accept a position that would earn him extra money and so Kokalj hired him as an outworker for Slovenijales. It was

49 Zayavlenie MID SSSR. Izvestiya (182), 02 August 1991: 6.

50 Interv'iu s Milanom Kuchanom: Voyna eshche ne konchilas'. Novoe vremya (32), 06 August 1991: 21. 
Kokalj, by then Slovenia's official representative in the Soviet Union, who notified Ljubljana of Ukraine's official recognition of Slovenia. A few days before Christmas (on 18 December 1991), Slovenian Foreign Minister Dr. Dimitrij Rupel sent a letter to his Ukrainian colleague Anatoly M. Zlenko expressing satisfaction with the countries' mutual recognition and commending Roman Kokalj as Slovenia's authorised representative and the head of the Slovenijales branch office in Moscow. In his next letter (on 19 December 1991), Rupel proposed that Ukraine and Slovenia establish diplomatic relations. ${ }^{51}$

The decision on the recognition of new states within the territory of the disintegrating Yugoslavia took significantly longer for the Russian Federation than it did for the aforementioned former Soviet republics and the European Community. The coordination between the Russia foreign affairs ministry and the responsible parliamentary committee reached a decisive point in December 1991 and January 1992 respectively. While the diplomatic documents available are not very revealing, it is nevertheless evident that the Committee on International Affairs and External Trade of the Supreme Soviet asked the Third European Administration of the USSR MFA to prepare the document 'Current Concerns regarding Developments in Yugoslavia and Proposed Guidelines for our Relations,' which was signed by Deputy Minister of Foreign Affairs Kolokov. ${ }^{52}$ On 29 December 1991, Kolokolov also wrote to Andrei Kozyrev:

The situation has reached a boiling point and we must urgently define our position regarding the crisis in Yugoslavia, including the question of recognising the former Yugoslav republics. ${ }^{53}$

On 13 January 1992, Kolokolov notified Kozyrev of the ongoing discussions in the aforementioned committee:

We have been actively addressing the issue of the recognition of Slovenia and other Yugoslav republics and the establishing of diplomatic relations. There is to be a discussion soon on the subject in the Committee on International Affairs and External Trade of the Supreme Soviet. The minutes with our suggestions have been sent to V. P. Lukin at your behest. Pending the committee's discussion of the issue and the final decision of the Russian governing bodies, it would

51 Consul General Y. Girenko sent translations of the correspondence between Rupel and the Ukrainian side to the foreign affairs ministry. In: Istoriko-diplomaticheskoe upravlenie MID SSSR, Arkhiv vneshney politiki SSSR, Fond 144 3EU, REFERENTURA PO YUGOSLAVII, 110 - POLITICHESKIE VOPROSY, Opis 52, Delo 6, Papka 124, Eks. 2, Ish. 505, 24 December 1991, Vh. 36 - 3EU, 04 January 1992.

52 Istoriko-diplomaticheskoe upravlenie MID SSSR, Arkhiv vneshney politiki SSSR, Fond 144 3EU, REFERENTURA PO YUGOSLAVII, Opis 53, Delo 5, Papka 128, 110 POLITICHESKIE VOPROSY, 6/3EU, 4. 1. 1992.

53 Istoriko-diplomaticheskoe upravlenie MID SSSR, Arkhiv vneshney politiki SSSR, Fond 144 3EU, REFERENTURA PO YUGOSLAVII, Opis 53, Delo 5, Papka 128, 110 POLITICHESKIE VOPROSY; Ish. 1829/3EU, 29 December 1992. 
be best to refrain from direct contact and correspondence on this subject with the Slovenian representatives. ${ }^{54}$

On his return to Moscow from Bonn in January 1992, Minister Kozyrev hinted to Izvestiya's diplomatic correspondent, Maxim Yusin, that the Russian Federation was changing its position:

The decision of the European Community has set in motion an irreversible process. As you know, Russia was not overly active regarding the recognition of the former Yugoslav republics. In light of our special relations with Belgrade, that was perhaps understandable - a Slavic factor, if you will. But today we can no longer ignore the political reality and fall behind our partners in the European process (Yusin 1992a: 1, 4).

On 24 January 1992, Deputy Minister Kolokolov wrote to inform Kozyrev about the ongoing preparations for the recognition of Slovenia and Croatia. He proposed the following plan of action: on 27 January 1992, a special Russian envoy would notify the Yugoslav foreign affairs ministry of Russia's intention to recognise Slovenia and Croatia, explaining Russia's motives for doing so and emphasising its willingness to continue good relations and cooperation with Yugoslavia. The envoy would then meet with the foreign affairs ministers of Serbia and Montenegro and assure them that their traditional friendly ties with Russia would remain unchanged. The day after the envoy arrived and once Moscow had received his telegram conveying Belgrade's response, Russia would declare its simultaneous recognition of Slovenian and Croatian independence 'and, in doing so, withdraw its past reservations for expressing sincere support for recognition. ${ }^{55}$

President Yeltsin announced Russia's intention to recognise both Slovenia and Croatia on 31 January 1992 during his visit to Washington (Gus'kova 1993: 225). Then, on 11 February 1992, at a meeting with representatives of the diplomatic corps in Moscow, he emphasised that Russia was gaining new friends and allies while in no way rejecting all the positive achievements of Yeltsin's predecessors (Gus'kova 1993: 68). That same day, Consul Marusin and Attaché Nikiforov of the consulate-general in Zagreb sent a summary report to Moscow, detailing the process of Western countries' recognition of Slovenia and Croatia. The report also noted that some countries would not recognise

54 Istoriko-diplomaticheskoe upravlenie MID SSSR, Arkhiv vneshney politiki SSSR, Fond 144 3EU, REFERENTURA PO YUGOSLAVII, Opis 53, Delo 8, Papka 129, 710 SPRAVKI PO POLITICHESKIM VOPROSAM, 3EU MID SSSR, Eks. 1, Vh. 43, 21 January 1992.

55 Istoriko-diplomaticheskoe upravlenie MID SSSR, Arkhiv vneshney politiki SSSR, Fond 144 3EU, REFERENTURA PO YUGOSLAVII, Opis 53, Delo 8, Papka 129, 710 SPRAVKI PO POLITICHESKIM VOPROSAM, 3EU MID SSSR, 639/ShChS-ns / 1700/OS-ns. 
Croatia until certain constitutional amendments had been made in regard to national minorities. The United States was expected to declare its recognition by mid-February, Marusin and Nikiforov agreed, anticipating that it would opt for conditional recognition and delay full diplomatic relations:

\begin{abstract}
Also, by quoting G. Bush, the media emphasised that the United States has not yet recognised the breakaway republics of Yugoslavia so as not to 'thwart the UN's peace-seeking efforts' and that, for the time being, it is in no hurry to 'follow the EC's lead.' There is a general and well-grounded assumption among observers here that the United States will give its recognition once the UN operation commences in Croatia. ${ }^{56}$
\end{abstract}

The consul and attaché reported that the Slovenian and Croatian media were buzzing with speculation that Russia would recognise these states as well. In their view, this was the reason behind the anticipated arrival of Special Mission Ambassador Yuri Deryabin.

Both Croatia and Slovenia have great interest in gaining Russian recognition and establishing diplomatic relations with the Russian Federation at the embassy level. Slovenia and Croatia envisage establishing a Russian embassy in Ljubljana and Zagreb, respectively. If, for financial reasons, that should not prove possible, they would consider it acceptable if our interests were represented by the Russian Federation ambassador to Austria while Zagreb and Ljubljana establish separate diplomatic missions. ${ }^{57}$

On 19 February 1992, five days after Russia's recognition of Slovenia, Deputy Minister Kolokolov wrote a special letter to Kozyrev, notifying him of the exchange of diplomatic notes, which had taken place outside the originally planned day (Consul Y. Girenko presented the notes in Ljubljana and Zagreb on 14 and 17 February, respectively):

President Tuđman received the note in Croatia and responded immediately - by writing to Yeltsin that same day. In the letter, he conveyed his gratitude and an invitation to commence talks on the establishment of diplomatic relations. Slovenian Foreign Minister Dimitrij Rupel, who received the note in Ljubljana, also addressed the issue of embassies. Both Slovenia and Croatia would like to hold these talks in Moscow, preferably within the framework of their for-

56 Istoriko-diplomaticheskoe upravlenie MID SSSR, Arkhiv vneshney politiki SSSR, Fond 144 3EU, REFERENTURA PO YUGOSLAVII, Opis 53, Delo 8, Papka 129, 710 SPRAVKI PO POLITICHESKIM VOPROSAM, Eks. 1, Ish. 40, 11 February 1992, O priznanii nezavisimosti Khorvatii i Slovenii i ustanovlyenii s nimi diplomaticheskih otnošeniy (Kratka informatsiya).

57 lbid. 
eign ministers' working visits to Russia. [...] Until diplomatic relations are established, the two governments have made a reasonable request that their interests in Moscow be represented by the heads of corporations accredited in Russia (i.e. R. Kokalj and M. Devičić) while Russia's interests in the new states during this transitional period will be represented by the Consulate General of the Russian Federation in Zagreb. ${ }^{58}$

On 28 February 1992, Girenko, the Russian consul-general in Zagreb, sent his own report, enclosing the official statement that he had cited in interviews with the Slovenian and Croatian media:

The new Russia is embarking on an open policy of broad cooperation, free of ideological dictates and imperial ambitions; hence it finds "double standards" strange: having won its own right to freedom, independence and democracy, Russia cannot deny the same rights to other countries; one cannot value their own freedom without equally honouring the independence of others as well as their right to their own socio-political choices. Russia has accepted the political reality in Yugoslav territory, especially the fact that the majority population in Slovenia and Croatia voted in the referendum for an autonomous and independent future. Therefore, Russia can no longer stand idly by in the process of their recognition on the basis of the criteria set by the European Community, i.e. the inviolability of borders and protection of national minority rights in accordance with European standards. At the end of January, the Russian government took a principled political decision to recognise Slovenia and Croatia as independent sovereign countries and new members of the international community of nations. Accordingly, the Russian President B. N. Yeltsin has initiated efforts towards official recognition on the basis of bilateral consultations with the state leaders of Serbia, Montenegro, Croatia and Slovenia, during which it will explain the grounds for its decision. ${ }^{59}$

\section{Perturbations in Belgrade}

Russia's decision to recognise Slovenia and Croatia provoked an indignant response from the Yugoslav government. The available diplomatic sources, comprising Soviet - or rather, Russian - embassy archives in Belgrade, do not

58 Istoriko-diplomaticheskoe upravlenie MID SSSR, Arkhiv vneshney politiki SSSR, Fond 144 3EU, REFERENTURA PO YUGOSLAVII, Opis 53, Delo 8, Papka 129, 710 SPRAVKI PO POLITICHESKIM VOPROSAM, 3EU MID SSSR Vh. 170, 24 February 1992 ( 3661/OS-ns).

59 Istoriko-diplomaticheskoe upravlenie MID SSSR, Arkhiv vneshney politiki SSSR, Fond 144 3EU, REFERENTURA PO YUGOSLAVII, Opis 53, Delo 8, Papka 129, 710 SPRAVKI PO POLITICHESKIM VOPROSAM, Eks. 1, Ish. 44, 28 February 1992, O vruchenii not MID Rossiskoy federatsii o priznanii gosudarstvennoy nezavisimosti Khorvatii i Slovenii (Informatsiya). 
include Yugoslav dispatches, but the atmosphere that pervaded Belgrade is more than aptly summed up by the news headlines:

'Stab in the back of Yugoslavia,' 'Europe slides back into chaos' are just two headlines from the covers of today's newspapers. [...] So then: euphoria in Slovenia and Croatia and countries openly sympathetic to them; anxiety and utter consternation in Belgrade and a series of other capitals (Fadeyev 1992: 5).

Although Serbia's open exasperation placed Russia in an awkward position, Russia decided to respond nevertheless. Failing to do so would have been contrary to well-established diplomatic practice and perceived as not only ignoring Yugoslavia's request to present a diplomatic note to the Russian Federation government, but also, to a certain degree, as a nod by Moscow to Belgrade's harsh criticism of Russia's stance. ${ }^{60}$ The author of the aforementioned instruction, Y. Agayev, advised Head of Third European Administration of USSR MFA O. Kabanov, to respond with restraint and equilibrium and state in very calm tones and short sentences that the Russian government had taken note of the Yugoslav position on the matter and wished to continue their close cooperation in the future. ${ }^{61} \mathrm{It}$ was precisely in connection with reassuring Belgrade and including all parties in the process that Consul General Girenko reported that their special envoy Deryabin had conducted talks in Belgrade on 05 February 1992 and the following day in Ljubljana and Zagreb:

In no sense, ethically, ideologically or religiously, does Russia support one Yugoslav republic over the other. Rather, it wishes to maintain friendly relations with all of them, including Croatia and Slovenia without harming its relations with Serbia and Montenegro, and vice versa. We firmly reject attempts. from whichever side they came, to cause trouble over religious matters between Russia and its old friends in the Balkans, with insinuations that Russia is trying to form a kind of "Orthodox axis" in the Balkans. Such allegations are nothing more than malicious fabrications. ${ }^{62}$

60 Istoriko-diplomaticheskoe upravlenie MID SSSR, Arkhiv vneshney politiki SSSR, Fond 144 3EU, REFERENTURA PO YUGOSLAVII, Opis 53, Delo 8, Papka 129, 710 SPRAVKI PO POLITICHESKIM VOPROSAM, 3EU MID SSSR Vh., 179, 26 February 1992 (25 February 1992, 65/uop, 2-mk/VS, 25 February 92).

61 lbid.

62 Istoriko-diplomaticheskoe upravlenie MID SSSR, Arkhiv vneshney politiki SSSR, Fond 144 3EU, REFERENTURA PO YUGOSLAVII, Opis 53, Delo 8, Papka 129, 710 SPRAVKI PO POLITICHESKIM VOPROSAM, Eks. 1, Ish. 44, 28 February 1992, O vruchenii not MID Rossiskoy federatsii o priznanii gosudarstvennoy nezavisimosti Khorvatii i Slovenii (Informatsiya). 


\section{Establishing Diplomatic Relations}

Diplomatic relations between the Republic of Slovenia and the Russian Federation were officially established on 25 May 1992, with the signing of an appropriate protocol in Ljubljana. Kokalj described the preparations with enthusiasm and emotion. The Russian foreign ministry had made no public announcements of its intentions. Kokalj simply received an invitation to formally accompany Foreign Minister Andrei Kozyrev to Vnukovo airport. The Minister was setting out on a tour through all six former Yugoslav republics and then heading to Lisbon to attend a conference on international community aid to the Commonwealth of Independent States. The Yugoslav embassy delegation, too, received an invitation to Vnukovo, where they flatly ignored Kokalj and his wife. At the time, they must have had a sense of what was coming. The matter was cleared by Deputy Foreign Minister Kolokolov, who arrived in the airport hall a few minutes before Kozyrev:

He looked around, smiled, bowed his head and started walking purposefully towards me. Just a few metres away, he stopped suddenly and walked away with the same air of purpose in the direction of where the Yugoslav delegation was seated. It looked larger than it really was. Their voices became increasingly animated. Murmuring with satisfaction, while the rest of the hall grew silent, looking towards the left corner. My wife and I stood there alone, humiliated. I said to myself: Don't show them how you feel. Then again, restraint wasn't really necessary since everyone was looking the other way. The next thing I knew, Kolokolov approached me with Chargé D’affaires Lazić on his arm. Speaking plainly and directly as was his custom, Kolokolov said: 'I am sure, Mr. Kokalj that Mr. Lazić does not know you yet; but he should. The thing is that Mr. Kokalj is here today in a special capacity, as the representative of a new state, which Russia has established diplomatic relations with.' That is how he introduced me, and Lazić could only say: 'Yes, I know him!' (Kokalj 2006: 20).

Kozyrev's tour of the six former Yugoslav republics was to include a visit to besieged Sarajevo with a special mediation mission. A JNA helicopter managed to take him to Bosnia and Herzegovina's capital from Belgrade, but after a few hours there, his visit was cut short by the Crimean crisis. On President Yeltsin's orders, he returned to Moscow to attend the Supreme Soviet meeting. ${ }^{63}$ He visited Ljubljana on 25 May 1992, flying directly from Lisbon:

63 Russian parliament held urgent discussions over the Crimean crisis, which has threatened up until recently to harm the relationship between the new states, the Russian Federation and Ukraine, both Soviet republics. On 05 May 1992, the parliament of the Autonomous Republic of Crimea declared its independence, and the following day, Ukrainian parliament adopted the Crimean Constitution, which stated in its preamble that the peninsula was part of Ukraine. A series of tense polemics followed, lead- 
The tour started on Monday in Slovenia. The Minister talked to the state leaders, signed the protocol on establishing diplomatic relations and then set out to Croatia... (Yusin 1992 b: 4).

Izvestiya dryly reported on the commencement of diplomatic relations between Slovenia and the Russian Federation; this dryness was characteristic of all Russian media reports on the subject. Roman Kokalj is more expressive in his memoirs, revealing that due to an unfortunate set of circumstances the Russian diplomats had to wait several hours in Lisbon ${ }^{64}$ before they could fly to Ljubljana, and they arrived at their Brdo residencerather tired. While impressed with the castle and its surroundings, they kept the meeting with Minister Rupel short:

That was the grandest diplomatic occasion in independent Slovenia. It was the first time that a foreign minister from another country had personally flown to Slovenia to sign an agreement on the establishment of diplomatic relations. This great country, a founding member of the UN Security Council, showed us an immense honour. [...] The Russian political leadership looked very favourably on Slovenia; they liked our way of working and considered Slovenia as an exemplary modern state even though it had just barely come into existence. Once signed, the protocol also set the principles of action for both sides concerning succession issues in the USSR and SFRY (Kokalj 2006: 21-22).

\section{Evolution of Russian Foreign Policy}

Mikhael Gorbachev's Perestroika, the collapse of the Soviet Union and the first presidential term of Boris Yeltsin represent a special period in the formation of Russian foreign policy. Gorbachev's concept of 'new political thinking' (Tsygankov 2008: 50) broke with the policy of confrontation with the West and the arms race and stressed the importance of international organisations. The key principles of Gorbachev's new thinking were de-ideologisation and a departure from the basic postulates of Marxism-Leninism in interstate relations (Georgieva - Georgiev 2006: 309). Andrei Tsygankov (2008: 32) considers that the development of this foreign policy was based on a concept of identity, which

ing ultimately to an agreement in June 1992 that Crimea would remain in Ukraine as an autonomous republic.

64 Kokalj refers to Barcelona, but there are several inaccuracies in his memoirs. Kozyrev attended the conference on aiding the Commonwealth of Independent States, which was held in Lisbon, not in Barcelona; he also provides wrong dates for Russia's recognition of Slovenia (suggesting 18 February instead of the correct 14 February) and Croatia (24 February instead of 17 February). He writes mistakenly that the United States recognised Slovenia six months after Russia established diplomatic relations with Slovenia when in reality the US recognition was granted on 07 April 1992 less than two months after that of Russia. 
defines notions of national interests. Gorbachev was interested in achieving transformation through the creation of a new socialist man. Yeltsin and his foreign minister, Andrey Kozyrev pushed the policy of "transformation" even further by proclaiming that complete integration with the Western system was Russia's foreign policy priority. They rejected the model of the Soviet man and instead strove to construct a new identity for Russia as part of the West. As a consequence, the national interest was equated with integration with Western economic institutions and security system. Although Kozyrev drew on Perestroika's premises, he was also critical of the concept:

[...] the makers of Perestroika displayed an all-too-obvious desire to merely colour the façade of the system, to humanise it "little by little" and invent its own "Prague Spring" to create socialism with a human face. Today, with the benefit of hindsight, I can only say that the principal mistake lay in the failure to understand the complete condemnation of the Bolshevik system. The decision to renounce violence actually ate away at the support structure of the regime, which soon then began to crumble. And equally inconsistent was its restoration... (Kozyrev 1992a: 3).

Neither Gorbachev nor the so-called young reformers of the new Russia had a genuine concern for Eastern Europe and the Balkans. Rather, they were focused on pursuing their own interests through dialogue with the United States and Western Europe. But the European east and southeast nevertheless posed a challenge to their policy. Once Gorbachev had granted them "freedom of choice" and Russia had "isolated "itself from the remaining post-Soviet expanse, Moscow renewed its interest in the former Soviet republics in 1993. The aforementioned steadfast support for the unity and territorial integrity of Yugoslavia was therefore not surprising. Positions began to change after the August coup, and they completely evolved with the collapse of the Soviet Union. Russia, which, to quote Kozyrev, aimed to step in line with 'civilised countries,' could not afford to fall behind. At the same time, the recognition of the new post-Yugoslav states and adoption of critical distance towards Serbia in the spring of 1992 had strong internal political connotations:

If the Russian Federation were to recklessly support only Serbian national-Bolsheviks out of all the Southern Slavs, it would be left in isolation in the Balkans, in the CSCE and in the UN. The fact, however, that Russia itself would suffer betrayal is equally important. After all, in Moscow today essentially the same forces are consolidating as they are in Belgrade. They are trying to push us into the same abyss. With Bolshevik straightforwardness, they are replacing the communist mythology with a pseudo-patriotic mythology, placing the same reliance on arguments of force instead of the force of arguments (Kozyrev 1992 b: 4). 
May 1992 brought about one of the major shifts in Russian policies on the Balkans. On 12 May 1992, Russia opposed the exclusion of the Federal Republic of Yugoslavia from the CSCE in Helsinki. Nevertheless, during a critical vote on 30 May in the UN Security Council, it voted in favour of international sanctions against Belgrade rather than abstain from voting, a move which would have put it on the same bench as China and Zimbabwe (Kandelj 1992: 32):

Russia is doing its utmost to strengthen the traditional links of friendship and cooperation with the Yugoslav nations, to restore peace to their land, to guarantee their freedom and independence. That is the significance of the unprecedented steps we have taken recently with regard to Serbia, Croatia and all the sovereign states that have been formed in the territory of the former Yugoslavia. However, so far, Belgrade has not heeded our good advice and warnings and failed to comply with the demands of the international community. By doing so, it has brought upon itself the UN sanctions. In voting for these sanctions, Russia fulfilled its obligation as a superpower for the maintenance of international law and order... (Gus'kova 1993: 71).

At a press conference, the Russian foreign ministry's spokesperson, Sergey Yastrzhembsky, admitted to a shift in foreign policy. In his words, Russia had done more than any other world power to promote a solution to the conflict in Yugoslavia. To support the sanctions was a 'difficult step, and it had taken it with a heavy heart' (Gus'kova 1993: 228). During his tour of the former Yugoslav republics in May 1992, Kozyrev met with Slobodan Milošević twice, but the two were unable to find common ground. Milošević claimed that Serbia was not formally involved in the conflict and had no influence on the Serbs in Bosnia and Herzegovina. In an interview with Izvestiya, the Russian foreign minister, thus, only concluded as follows:

Unfortunately, there are forces that ignore friendly advice and understand only the language of dictate. They have obviously underestimated the role of Russia as a superpower... Being friendly is something other than showing leniency to those who clearly breach the principles of the CSCE. I wish Belgrade would understand that (Yusin 1992c: 6).

The course that Russian foreign policy was taking provoked sharp polemics from the Russian public. The newspaper Moskovskie novosti featured a diametrically opposed viewpoint written by the academic Pavel Volobuev and scholar Lyudmila Tyagunenko from the Russian Academy of Sciences:

We have not forgotten the solemn announcement of the heads of the Russian foreign ministry of a fundamentally new foreign policy concept, which is the 
aspiration of the new Russia. However, an objective look at some episodes in the foreign political activities of the Russian government raises the following question: Does this perhaps mean that Russia has relinquished its independent foreign policy? [...] It could hardly find a more inappropriate moment to sign the documents on establishing diplomatic relations with Croatia and Slovenia. Did this not amount - even inadvertently - to unilateral support of Croatia? And what kind of a stance, if not unilateral, did the Russian foreign minister assume in regard to Serbia when he joined the initiative of the United States and European states, EC members, who are apparently not in the least bothered by numerous casualties among the Serbian population? (Volobuev - Tyagunenko 1992: 13).

Further reservations were expressed over the recognition of the newly created states in the former Yugoslavia's territory, and hence, of the disintegration of the federation as such. Vadim Medvedev (1994: 506-507) was critical of how the Yugoslav issue had been treated within the context of the disintegration of the Soviet Union:

The measures taken by the Russian leadership towards the strengthening of the sovereignty of the Russian Federation - giving momentum to the centrifugal forces in the other republics - led to the disintegration of the union. Not so much through constitutional as through radically destructive neo-Bolshevik methods. From this viewpoint, the Russian stance towards Yugoslavia seems logical enough although not perfect; to be honest, it is a wrong one: it sends a strong signal in support of disintegration processes and unilateral secessions of the republics from the federation.

The Russian academic and the broader public, thus, had a uniform understanding of Russian policy in the Balkans:

The enthusiastic recognition of Slovenian and Croatian independence just poured more oil on the crisis in the region. With no effective mechanism to contain the conflict and settle it through peaceful means, it exploded into a bloody civil war that engulfed nearly the entire territory of the former Yugoslavia. [...] The attitude of the Soviet leadership towards the war makes little sense. The same may be said for many aspects of Gorbachev's politics. By 1991, the Soviet leadership had finally lost its political freedom and turned [...] into a collective political eunuch. Straining for the short-lived effect of implementing the "new political thinking," Gorbachev and his crew did not take care to protect state-national interests. The international authority of the Soviet Union was melting catastrophically under the radiating "Prague Spring," with the betrayal of former allies at both the state and personal levels. When Gorbachev decided to take on the role of peace mediator in the negotiations between the Serbian 
and Croatian presidents with no tangible plan, the international community looked down on these endeavours with no expectation that anything good would come out of the meeting. The Soviet Union had ample reasons to exert its influence over the developments in Yugoslavia. No one drove us out but ourselves; we left the region voluntarily (Ponomareva 2007: 134).

\section{Conclusion}

The diplomatic material available reveals the restraint with which the Soviet diplomats approached emancipatory processes in the former Yugoslav republics. Officials at the Soviet embassy in Belgrade and the consulate-general in Zagreb viewed the developments in Yugoslavia within the context of disintegration processes in their own country. It was not until after the ten-day war in Slovenia that the Zagreb consulate-general finally warned the foreign ministry in Moscow that the situation on the ground had changed to the extent that a change in official positions was urgently required. The unsuccessful attempted coup that took place between 19 and 22 August 1991 in the Soviet Union compelled the Russian foreign ministry to gradually soften its view that Yugoslavia should preserve its unity and territorial integrity - a last-ditch attempt at mediation came in the form of Gorbachev's invitation to Serbian and Croatian presidents Milošević and Tuđman to take part in consultations in Moscow on 15 October 1991 - but the ministry did not break with the old foreign policy until the collapse of the Soviet Union. While the diplomatic sources available cast light on the internal mechanisms for reporting on conditions and on decisions made about the recognition of new states, the motives for that recognition are more elaborately explained in the official statements of Russian authorities, especially the interviews with Foreign Minister Andrei Kozyrev in the Russian media. Russia wanted to become part of the West so as not to lag behind in political terms. The same period, however, witnessed growing internal antagonisms between President Yeltsin's circle on the one hand and, on the other, the conservative and Communist opposition whom the President's close associates considered ideationally akin to government circles in Belgrade. Slovenia first sought to establish cooperation with some Soviet republics at an inter-republican level and then tried to talk Moscow into recognising its barely established statehood. However, given the considerations revealed by diplomatic sources and media assessments as well as in the memoirs and diaries of influential figures in the Soviet Union, it is safe to assume that the recognition of Slovenia's independence was more a consequence of the narrow "window" that opened with the collapse of the Soviet Union and then quickly closed due to the internal situation in the Russian Federation. Yeltsin's reforms provoked a growing revolt among Russians; state foreign policy came under increasingly scathing criticism and 
the opposition increased faster than Yeltsin's associates had expected. As concerns the Yugoslav crisis, Serbia, which had advocated for the longest for the existence of the Yugoslav federation, soon became the target of Western critics. This quickly stirred and strengthened Russia's traditional solidarity with Serbia.

\section{References}

- Istoriko-diplomaticheskoe upravlenie MID SSSR, ARKHIV VNESHNEY POLITIKI SSSR, Fond 202, Posol'stvo SSSR v SFRYu.

- ISTORIKO-DIPLOMATICHESKOE UPRAVLENIE MID SSSR, ARKHIV VNESHNEY POLITIKI SSSR, Fond 144, 3EU, Referentura po Yugoslavii.

(1991): Interv'iu s Milanom Kuchanom: Voyna eshche ne konchilas'. Novoe vremya (32), 6 August 1991: 21.

(1991): Iz zayavleniya MID SSSR. Izvestiya (222), 17 September 1991: 5.

(1991): Zayavlenie MID SSSR. Izvestiya (182), 2 August 1991: 2.

Archive of the Ministry of Foreign Affairs of the Russian Federation:

Chernyaev, Anatoli (2008): Sovmestnyi ishod. Dnevnik dvuh epoh 1972-1991. Moscow.

Fadeyev, Yevgeni (1991): Razvyazivaniye uzlov nachalos'. Pravda, 10 June 1991: 5.

Fadeyev, Yevgeni (1992): Proshchay, federativnaya Yugoslaviya! Pravda, 17 January 1992: 5.

Georgieva, Natalya - Georgiev, Vladimir (2006): Istoriya Rossii. Moscow: MGU, Velbi.

Gorbachev, Mikhail (1987): Perestroika i novoe myshlenie dlia nashei strany i dlia vsego mira. Moscow: Politizdat.

Gorlov, Vladimir (1991): Voyna po-prezhnemu ba rasstoyaniy vystrela. Iz Belgrada... Komsomolska pravda, 16. October 1991: 3.

Gryzunov, Sergei - Romanenko, Sergei (2012): Raspad Yugoslavii, "perestroichny" SSSR i nezavisimaya Rossiya. Contribution presented at the International Conference "Twentieth Anniversary of the Collapse of the Soviet Union and Yugoslavia: New Findings and Lessons Learned." MGIMO University, Moscow, 20 February 2012.

Gus'kova, Yelena (ed.). (1993): Yugoslavskiy krizis i Rossiya: Dokumenty, fakty, kommentarii (1990-1993). Moscow: Fond Yugoslavyanskikh issledovaniy i sotrudnichestva "Slavyanskaya letopis"'.

Kandelj, Pavel (1992): Chto nam Balkani? Novoe vremya (25), 16 June 1992: 32.

Kokalj, Roman (2006): Moskovskie vospominaniya. Moscow: RAN.

Kozyrev, Andrei (1992a): Preobrazhennaya Rossiya v novom mire. Izvestiya (1), 2 January 1992: 3.

Kozyrev, Andrei (1992 b): Na ch'ey storone Rossiya v Yugoslavskom konflikte? Izvestiya (133), 8 June 1992: 4.

Medvedev, Vadim (1994): Raspad: Kak on nazreval v "mirovoy sisteme sotsializma". Moscow: Mezhdunarodnye otnosheniya. 
Pankin, Boris (1993): Sto oborvannykh dney. Moscow: Sovershenno sekretno.

Parad suverenitetov. Available at: https://ru.wikipedia.org/wiki/Парад_суверенитетов. (1 April 2015).

Ponomareva, Yelena (2007): Politicheskoe razvitie postyugoslavskogo prostranstva (vnutrennie i vneshnie faktory). Moscow: MGIMO University.

Ponomareva, Yelena (2010): Novye gosudarstva na Balkanah. Moscow: MGIMO University.

Razuvaev, V. (1991): Interv'iu s Andreem Kozyrevim: 100 dney ministra. Novoe vremya (9), 27 February 1991: 10.

Repe, Božo (2002): Jutri je nov dan. Slovenci in razpad Jugoslavije. Ljubljana: Modrijan.

Romanenko, Sergei. (2011): Mezhdu "Proletarskim internatsionalizmom" i "Slavyanskim bratstvom". Rossisko-yugoslavskie otnosheniya $v$ kontekste etnopoliticheskikh konfliktov $v$ Sredney Evrope (nachalo XX veka-1991 god.). Moscow: Novoe literaturnoe obozrenie.

Simoniti, Iztok (1996): Svet po l. 1990. In: Russet, Bruce - Starr, Harvey. (1996): Svetovna politika. Ljubljana: FDV.

TASS. (1991): Sovetsko-yugoslavskie peregovori. Izvestiya (183), 2 August 1991: 4.

Tsygankov, Andrei (2008): Vneshnyaya politika Rossii ot Gorbacheva do Putina. Moscow: Nauchnaya kniga.

Vasileva, N. - Gavrilov, V. - Mirkiskin, V. (2005): Balkanskiy uzel, ili Rossiya i "yugoslavskiy factor" $v$ kontekste politiki velikikh derzhav na Balkanah $v$ XX veke. Moscow, Zvonitsa-MG.

Volobuev, Pavel - Tyagunenko, Lyudmila (1992): "Srbskiy vopros" i interesi Rossii. Moskovskie novosti (25), 21 June 1992: 13.

Yusin, Maxim (1991): Posrednicheskaya missiya M. Gorbacheva, kazhetsia, udalas'. Izvestiya (247), 16 October 1991: 1.

Yusin, Maxim (1992a): Andrei Kozyrev: Zapad—estestvenny soiuznik novoy Rossii. Izvestiya (16), 20 January 1992: $1,4$.

Yusin, Maxim (1992c): Nad Belgradom sgushchaiutsia tuchi. Izvestiya (125), 29 May 1992: 6.

Yusin, Maxin (1992 b): V Lissabone vnov' obeshchana pomoshch' stranam SNG. Izvestiya (121), 25 May 1992: 4.

Andrej Stopar completed studies in comparative literature and history at the Faculty of Arts of the University of Ljubljana and is currently working towards a PhD within the humanities doctoral programme at the University of Nova Gorica, Slovenia. He is the editor-in-chief of the First and News programme of Radio Slovenia and was previously chief correspondent from the Russian Federation and CIS for RTV Slovenia (2005 - 2013). As an international politics commentator, he focuses mainly on events in Central and Eastern Europe. He is the author of the book Pax Putina (2014) and several documentary films for TV Slovenia. He can be reached at: andrej. stopar@rtvslo.si. 